\title{
Effects of Different Doses of Tilmicosin on Malondialdehyde and Glutathione Concentrations in Mice
}

\author{
E. YAZAR ${ }^{1}$, E. OZTEKIN ${ }^{2}$, A. SIVRIKAYA ${ }^{2}$, R. COL ${ }^{3}$, M. ELMAS ${ }^{1}$, A. L BAS 1
}

${ }^{1}$ Department of Pharmacology and Toxicology, Faculty of Veterinary Medicine, ${ }^{2}$ Department of Biochemistry, Faculty of Meram Medicine, ${ }^{3}$ Department of Physiology, Faculty of Veterinary Medicine, University of Selcuk, Konya, Turkey

Received July 7, 2003

Accepted February 11, 2004

\section{Abstract}

Yazar, E., E. Oztekin, A. Sivrikaya, R. Col, M. Elmas, A. L. Bas: Effects of Different Doses of Tilmicosin on Malondialdehyde and Glutathione Concentrations in Mice. Acta Vet. Brno 2004, 73: 69-72.

The aim of this study was to follow the effects of different doses of tilmicosin on malondialdehyde and reduced glutathione levels of heart and liver, and on selected haematological indices. Forty male Balb/C mice were used throughout the experiment. They were divided into four groups $(\mathrm{n}=10)$, and injected subcutaneously as follows: Group 1 (control), with isotonic saline solution, Group 2 with $25 \mathrm{mg} / \mathrm{kg}$ body weight of tilmicosin, Group 3 with $50 \mathrm{mg} / \mathrm{kg}$, and Group 4 with $75 \mathrm{mg} / \mathrm{kg}$ of tilmicosin in single injections. After three days, plasma, cardiac and hepatic malondialdehyde and reduced glutathione levels were measured with spectrophotometer. Red blood cell, white blood cell, platelet, haemoglobin, packed cell volume and percentage of leukocytes were also determined.

At the end of the experiment, tilmicosin did not cause any statistically significant $(P>0.05)$ changes in haematological parameters such as red blood cells, white blood cells, platelet, haemoglobin, packed cell volume and percentage of leukocytes. Hepatic malondialdehyde and reduced glutathione levels increased $(P<0.05)$ only at the highest dose of tilmicosin. The results indicate that tilmicosin did not cause lipid peroxidation in the heart.

Tilmicosin, heart, liver, lipid peroxidation, mouse

Antibiotics are the most widely used drugs in veterinary medicine. Antibacterials may cause different adverse or side effects. Adverse drug reactions are classified according to their etiology, and biochemical side effects are generally accepted as indicators of pathological side effects (Kay aalp 1994).

Tilmicosin has been prepared by chemical modification of desmycosin. It has been used in therapy of respiratory disease in cattle. It inhibits growth of Pasteurella spp. and Mycoplasma spp. Micotil $300{ }^{\circledR}$ (Lilly Elanco, Istanbul, Turkey), contains $300 \mathrm{mg}$ tilmicosin per milliliter, produces therapeutic levels in the lungs for 3 to 4 days after a single subcutaneous injection (Barragry 1994; Modric et al. 1999).

Gastrointestinal upset, jaundice and liver damage have been reported after administration of macrolides. In addition to these, tilmicosin has cardiotoxic effect. On the other hand, a transient swelling at the injection site, severe dyspnea, anaphylaxis and collapse after tilmicosin treatment (Jordan et al. 1993; McGuigan 1994; Barragry 1994) may occur. Tilmicosin decreased cardiac superoxide dismutase and glutathione peroxidase activities (Yazar et al. 2002).

Malondialdehyde (MDA) is formed during oxidative degeneration as a product of free oxygen radicals (Valenzuela 1990), which is accepted as an indicator of lipid peroxidation (Neils en et al. 1997). Glutathione peroxidase catalyses the reduction of hydrogen peroxide or lipid peroxides with reduced glutathione (GSH) (Chan and Decker 1994).

Address for correspondence:

Dr. Enver Yazar

Selcuk University, Veterinary Medicine

Dept. of Pharmacology and Toxicology

2031, Campus/Konya, Turkey
Phone: +90332241004

Fax: +903322410063

E-mail:eyazar@selcuk.edu.tr

ti://www.vfuszacta-vet/actavet htm 
The purpose of this study was to investigate the effects of different doses of tilmicosin on plasma, cardiac and hepatic MDA and GSH levels to determine the possible cardiotoxic and hepatotoxic effects, and investigate the effect of tilmicosin on haematological parameters.

\section{Materials and Methods}

Forty clinically healthy male Balb/C mice (aged approximately 3-3.5 months, body mass $28-36 \mathrm{~g}$ ) were used throughout the experiment (Animal Research Institute, Konya, Turkey). Mice were fed on a standard pellet diet and tap water ad libitum. They were divided in four groups of ten animals each. Mice were injected subcutaneously with: (Group 1 = control) isotonic saline solution, (Group 2) $25 \mathrm{mg} / \mathrm{kg}$, (Group 3) $50 \mathrm{mg} / \mathrm{kg}$ and (Group 4) $75 \mathrm{mg} / \mathrm{kg}$, body weight, tilmicosin (Micotil $300^{\circledR}$, Lilly Elanco, Istanbul, Turkey), single injection. Micotil $300 ®$ was diluted by propylene glycol (Merck, Darmstadt, Germany) to achieve 25,50 and $75 \mathrm{mg} / \mathrm{kg}$ doses.

At the end of the experiment, blood samples were taken from the heart by cardiac puncture under light ether anesthesia. Mice were then immediately killed by cervical dislocation. Liver and heart were removed immediately. Plasma, cardiac and hepatic MDA and GSH levels were determined by previously reported methods (Mihara and Uchiyama 1978; Ellmann 1959; Draper and Hadley 1990) with a spectrophotometer (Shimadzu UV-1601, Kyoto, Japan). Cardiac and hepatic MDA and GSH levels were expressed as nmol/g and $\mu \mathrm{mol} / \mathrm{g}$ tissue protein, respectively.

Red blood cell (RBC) and white blood cell (WBC) counts were obtained with a haemocytometer. Hemoglobin $(\mathrm{Hb})$ and packed cell volume (PCV) were determined by Sahli haemometer and microhaematocrit methods, respectively. Mean corpuscular volume (MCV), mean corpuscular haemoglobin $(\mathrm{MCH})$ and mean corpuscular haemoglobin concentration (MCHC) levels were calculated.

All values were expressed as mean \pm SE. Tukey multiple range test (SPSS for Windows, release 11.0) was used to determine statistical differences between control and experimental groups. In all cases, probability of error of less than $P<0.05$ was selected as the criterion for statistical significance from the control values.

\section{Results}

Effects of different doses of tilmicosin on plasma, cardiac and hepatic MDA and GSH levels, and haematological parameters are given in Table 1.

Table 1

Effects of different doses of tilmicosin on malondialdehyde and glutathione levels, and haematological parameters $($ mean \pm SE)

\begin{tabular}{|l|c|c|c|c|}
\hline Parameters & $\begin{array}{c}\text { Control } \\
(\mathrm{n}=10)\end{array}$ & $\begin{array}{c}25 \mathrm{mg} / \mathrm{kg} \\
(\mathrm{n}=10)\end{array}$ & $\begin{array}{c}50 \mathrm{mg} / \mathrm{kg} \\
(\mathrm{n}=10)\end{array}$ & $\begin{array}{c}75 \mathrm{mg} / \mathrm{kg} \\
(\mathrm{n}=10)\end{array}$ \\
\hline $\mathrm{MDA}_{\text {plasma }} \mathrm{nmol} / \mathrm{ml}$ & $4.04 \pm 0.26$ & $3.96 \pm 0.17$ & $3.88 \pm 0.15$ & $4.15 \pm 0.16$ \\
\hline $\mathrm{MDA}_{\text {hepatic }} \mathrm{nmol} / \mathrm{g}$ & $24.08 \pm 2.39$ & $28.13 \pm 3.97$ & $22.55 \pm 1.10$ & $42.21 \pm 2.06^{*}$ \\
\hline $\mathrm{MDA}_{\text {cardiac }} \mathrm{nmol} / \mathrm{g}$ & $19.10 \pm 1.76$ & $19.43 \pm 0.70$ & $17.93 \pm 1.01$ & $17.19 \pm 0.97$ \\
\hline $\mathrm{GSH}_{\text {hepatic }} \mathrm{\mu mol} / \mathrm{g}$ & $14.90 \pm 1.88$ & $14.78 \pm 1.01$ & $11.42 \pm 0.76$ & $22.43 \pm 2.61^{*}$ \\
\hline $\mathrm{GSH}_{\text {cardiac }} \mu \mathrm{mol} / \mathrm{g}$ & $4.45 \pm 0.21$ & $4.07 \pm 0.18$ & $4.07 \pm 0.50$ & $3.34 \pm 0.18$ \\
\hline${\mathrm{RBC}\left(\times 10^{6} \cdot \mu \mathrm{l}\right)}^{\mathrm{WBC}\left(\times 10^{3} \cdot \mu \mathrm{l} / 1\right)}$ & $8.46 \pm 0.4$ & $7.60 \pm 0.31$ & $7.98 \pm 0.94$ & $7.71 \pm 1.09$ \\
\hline Platelet $\left(\times 10^{3} \cdot \mu \mathrm{l} / 1\right)$ & $4.28 \pm 0.27$ & $4.17 \pm 0.32$ & $4.29 \pm 0.51$ & $4.17 \pm 0.50$ \\
\hline Haemoglobin $(\mathrm{g} / 100 \mathrm{ml})$ & $992.1 \pm 38.78$ & $942.2 \pm 60.86$ & $1032 \pm 134.22$ & $1005 \pm 43.43$ \\
\hline PCV $(\%)$ & $41.89 \pm 0.16$ & $11.10 \pm 0.23$ & $11.25 \pm 1.06$ & $10.96 \pm 0.20$ \\
\hline Monocytes $(\%)$ & $2.14 \pm 0.55$ & $3.85 \pm 0.56$ & $3.14 \pm 0.46$ & $2.86 \pm 0.45$ \\
\hline Neutrophils $(\%)$ & $34.85 \pm 3.93$ & $28.57 \pm 3.68$ & $21.71 \pm 5.96$ & $21.55 \pm 2.14$ \\
\hline Lymphocytes $(\%)$ & $62.86 \pm 3.90$ & $66.14 \pm 3.97$ & $74.71 \pm 1.86$ & $73.43 \pm 13.36$ \\
\hline Basophils $(\%)$ & $0.43 \pm 0.20$ & $0.29 \pm 0.18$ & $0.00 \pm 0.00$ & $0.14 \pm 0.14$ \\
\hline Eosinophils $(\%)$ & $1.00 \pm 0.58$ & $1.14 \pm 0.69$ & $0.42 \pm 0.03$ & $0.86 \pm 0.38$ \\
\hline MCV fl & $48.21 \pm 1.93$ & $51.67 \pm 1.89$ & $48.06 \pm 2.01$ & $52.66 \pm 2.96$ \\
\hline MCH pg & $14.25 \pm 0.61$ & $14.77 \pm 0.62$ & $14.21 \pm 0.57$ & $14.43 \pm 0.54$ \\
\hline MCHC g/dl & $29.56 \pm 0.33$ & $28.58 \pm 1.48$ & $29.65 \pm 0.63$ & $27.45 \pm 0.89$ \\
\hline
\end{tabular}

* Statistically different from control values $(P<0.05)$. MDA; malondialdehyde, GSH; reduced glutathione, $\mathrm{RBC}$; red blood cell, WBC; white blood cell, PCV; paced cell volume, MCV; mean corpuscular volume, $\mathrm{MCH}$; mean corpuscular haemoglobin, $\mathrm{MCHC}$; mean corpuscular haemoglobin concentration. 
Blood cell counts slightly decreased in the experimental groups, but it was not statistically significant $(P>0.05)$. Hepatic MDA and GSH concentrations only increased in Group 4 $(P<0.05)$.

\section{Discussion}

Tilmicosin has been used for treatment of respiratory disease in animals such as cattle, swine (Moran et al. 1997), rabbit (Mckay et al. 1996) and rat (Modric et al. 1999). Macrolides are generally hepatotoxic (Barragry 1994). In addition, it is well known that tilmicosin has cardiotoxic effects. After tilmicosin injection, positive chronotropy and negative inotropy are observed (Jordan et al. 1993; Mc Guigan 1994).

In the present study, cardiac MDA and GSH did not change at any dose we used. In our previous studies, tilmicosin caused an increase in cardiac creatine kinase activity (Yazar et al. 2001) and decreases in cardiac superoxide dismutase and glutathione peroxidase activities in mice at the dose of $25 \mathrm{mg} / \mathrm{kg}$ (Yazar et al. 2002). In the present study, cardiac MDA, which accepted as an indicator of lipid peroxidation (Valenzuela 1990; Neilsen et al. 1997), was not affected. It may be stated that tilmicosin only depressed activities and/or synthesizes of superoxide dismutase and glutathione peroxidase.

In this study, tilmicosin caused increased hepatic MDA and GSH levels at the highest dose $(75 \mathrm{mg} / \mathrm{kg}$ ) in Group 4. Macrolides are metabolized by the liver. Therefore tilmicosin might have achieved a high concentration in the liver and cause changes in MDA and GSH concentrations. However, this increase of MDA level was not reflected in the plasma.

In the haematological analysis, tilmicosin caused slightly decreased RBC and WBC counts, but these decreases did not differ $(P>0.05)$. In the previous studies, tilmicosin caused statistically significant decrease in RBC and WBC counts of rabbits (Altu nok et al. 2002) and it achieved at high levels in phagocytes of avian, porcine and bovine (Scorne aux and Shryock 1999). Also, it was reported that other macrolides might cause similar effect. Azithromycin and clarithromycin decreased RBC and WBC counts in humans (Fujii et al. 1995; McEvay and Litvak 2001; Ohtsuka et al. 1996; Tajima et al. 1995).

Our results indicate that although tilmicosin caused increases in MDA and GSH levels at the highest dose $(75 \mathrm{mg} / \mathrm{kg})$ in the liver, it did not affect cardiac MDA and GSH levels, and haematological parameters. It may be stated that tilmicosin did not cause lipid peroxidation in the heart of Balb/C mice.

\section{Účinek různých dávek tilmicosinu na koncentraci malondialdehydu a glutathionu}

Tilmicosin má kardiotoxický účinek a po léčbě tímto preparátem byla pozorována positivní chronotropie a negativní ionotropie. Cílem této studie bylo zjistit účinek různých dávek tilmicosinu na koncentraci malondialdehydu, redukovaného glutathionu v srdci a játrech a na hematologické parametry. K experimentu bylo použito $40 \mathrm{Balb} / \mathrm{c}$ myší samčího pohlaví. Myši byly rozděleny do čtyř skupin $(n=10)$. Myším byly aplikovány s.c. injekce tilmicosinu $\mathrm{v}$ následujících dávkách: skupině 1 (kontrolní) byl podán izotonický fyziologický roztok, 2. skupině $25 \mathrm{mg} / \mathrm{kg}$, 3. skupině $50 \mathrm{mg} / \mathrm{kg}$ a 4 . skupině 75 $\mathrm{mg} / \mathrm{kg}$. Po 3 dnech byla pomocí spektrofotometru měřena koncentrace malondialdehydu a redukovaného glutathionu v krevní plazmě, v srdci a játrech. Byly též stanoveny počty červených a bílých krvinek, krevních destiček, hemoglobinu, hematokrit a diferenciální krevní obraz.

Na konci experimentu bylo zjištěno, že podání tilmocosinu nevyvolalo žádné statisticky významné změny $(P>0.05)$ sledovaných hematologických ukazatelů. Koncentrace malondialdehydu a redukovaného glutathionu v játrech se zvýšila pouze ve čtvrté skupině $(P<0.05)$. Tilmicosin tedy nezpůsobuje lipoperoxidaci v srdeční tkáni. 


\section{Acknowledgement}

This study was financed by SUBAPK (2002/061 Selcuk University, Konya, Turkey).

\section{References}

ALTUNOK, V, YAZAR, E, ELMAS, M, TRAS, B, BAS, AL, COL, R 2002: Investigation of haematological and biochemical side effects of tilmicosin in healthy New Zealand rabbits. J Vet Med B 49: 68-70

BARRAGRY, TB 1994: Veterinary Drug Therapy, Williams and Wilkins, Philadelphia, USA

CHAN, KM, DECKER, EA 1994: Endogenous skeletal muscle antioxidants. Crit Rev Food Sci Nutr 34: $403-426$

DRAPER, HH, HADLEY, M 1990: Malondialdehyde determination as index of lipid peroxidation. Methods Enzymol 186: 421-431

ELLMAN, GL 1959: Tissue sulfhydryl groups. Arch Biochem Biophys 82: 70-77

FUJII, R, ABE, T, TEJIMA, T, TERASHIMA, I, MEGURO, H, SUNAKAWA, K, YOKOTA, T, AKITA, H, IWATA, S, TAKEUCHI, Y 1995: PharmacoKinetic and clinical studies with azithromycin (capsule) in the pediatric field. Pediatric study group of azithromycin. Jpn J Antibiot 48: 1074-1092

JORDAN, WH, BYRD, RA, COCHRANE, RL, HANASONO, GK, HOYT, JA, MAIN, BW, MEYEHOFF, RD, SARAZAN, RD 1993: A review of the toxicology of he antibiotic Micotil 300. Vet Human Toxicol 35: 151-158 KAYAALP, SO 1994: Medical Pharmacology. $7^{\text {th }}$ Ed, Gunes Kitabevi Ltd. Sti, Ankara, Turkey

MCEVAY, GK, LITVAK, K 2001: AHFS Drug 2001 Information, American Society of Healthy System Pharmacists, USA

MCGUIGAN, MA 1994: Human exposures to tilmicosin. Vet Hum Toxicol 36: 306-308

MCKAY, SG, MORCK, DW, MERRIL, JK, OLSON, ME, CHAN, SC, PAP, KM 1996: Use of tilmicosin for treatment of pasteurellosis in rabbits. Am J Vet Res 57: 1180-1184

MIHARA, M, UCHIYAMA, M 1978: Determination of malonaldehyde precursor in tissues by thiobarbituric acid test. Anal Biochem 86: 271-278

MODRIC, S, WEBB, AI, DAVIDSON, M 1999: Effect of respiratory tract disease on pharcokinetics of tilmicosin in rats. Lab Anim Sci 49: 248-253

MORAN, JW, TURNER, JM, COLEMAN, MRJ 1997: Determination of tilmicosin in bovine and porcine sera by liquid chromatography. A O A C Int 80: 1183-1189

NEILSEN, F, MIKKELSEN, BB, NEILSEN, JB, ANDERSEN, HR, GRANDJEAN, P 1997: Plasma malondialdehyde as biomarker for oxidative stress: reference interval and effects of life-style factors. Clin Chemist 47: 1209-1214

OHTSUKA, Y, HARADA, Y, TSUJI, Y, UEHARA, Y, KIDO, T, KOBAYASHI, N, HAYASHI, K 1996: Pharmacokinetic and clinical studies on azithromycin in children. Jpn J Antibiot 49: 1039-1048

SCORNEAUX, B, SHRYOCK, TR 1999: The determination of the cellular volume of avian, porcine and bovine phagocytes and bovine mammary epithelial cells and its relationship to uptake of tilmicosin. J Vet Pharmacol Ther 22: 6-12

TAJIMA, T, KOBAYASHI, M, TERASHIMA, I, MEGURO, H, SUNAKAWA, K, YOKOTA, T, AKITA, H, IWATA, S, TAKEUCHI, Y, FUJII, R 1995: Pharmacokinetic and clinical studies with azithromycin (fine granule) in the pediatric field. Pediatric study group of azithromycin. Jpn J Antibiot 48: 1051-1073

VALENZUELA, A 1990: The biological significance of malondialdehyde determination in the assessment of tissue oxidative stress. Life Sci 48: 301-309

YAZAR, E, ALTUNOK, V, ELMAS, M, TRAS, B, BAS, AL, OZDEMIR, V 2001: Effect of tilmicosin on cardiac muscle and serum creatine kinase activities and serum total protein level in healthy male Balb/C mice. Revue Med Vet 152: 881-883

YAZAR, E, ALTUNOK, V, ELMAS, M, TRAS, B, BAS, AL, OZDEMIR, V 2002: The effect of tilmicosin on cardiac superoxide dismutase and glutathione peroxidase activities. J Vet Med B 49: 209-210 